\title{
Immunosuppression by D-Penicillamine In Vitro

\author{
Inhibition of Human T Lymphocyte Proliferation \\ by Copper- or Ceruloplasmin-dependent \\ Generation of Hydrogen Peroxide and \\ Protection by Monocytes
}

Peter E. Lipsky

Harold C. Simmons Arthritis Research Center and the

Department of Internal Medicine, The University of Texas

Health Science Center at Dallas, Southwestern

Medical School, Dallas, Texas 75235

bstract. It has been suggested that D-penicillamine is active in rheumatoid arthritis because of its capacity to function as a selective inhibitor of $\mathrm{T}$ lymphocyte function. The basis for the immunosuppressive action of this drug as well as mechanisms whereby the effect of D-penicillamine could be modified by elements of rheumatoid synovial tissue were examined. As previously reported, D-penicillamine, in the presence of copper ions markedly inhibited mitogen-induced human $T$ lymphocyte DNA synthesis. Since the vast majority of copper in the body exists as an integral part of the ceruloplasmin molecule, the capacity of this cuproprotein to augment D-penicillamine-mediated inhibition of $\mathrm{T}$ cell function was examined. The requirement for copper ions could be entirely replaced by purified ceruloplasmin, which had been depleted of nonspecifically bound copper by passage over Chelex- 100 columns. The mechanism by which D-penicillamine in the presence of either copper ions or ceruloplasmin caused inhibition of $T$ lymphocyte responsiveness was examined. Partial protection from this inhibitory effect was accomplished by sodium borohydride. While superoxide dismutase had no protective effect, catalase was found to protect lymphocyte responsiveness totally from the inhibitory action of D-penicillamine and either copper ions or ceruloplasmin. Similarly, horseradish peroxidase and myeloperoxidase also pro-

Dr. Lipsky is a recipient of National Institutes of Health Research and Career Development Award AM-00599. 1983.

Received for publication 16 May 1983 and in revised form 9 September

J. Clin. Invest.

(c) The American Society for Clinical Investigation, Inc.

$0021-9738 / 84 / 01 / 0053 / 13 \$ 1.00$

Volume 73 , January $1984,53-65$ tected responsiveness from these inhibitors while boiled catalase was without effect. These results indicate that inhibition of $T$ lymphocyte responsiveness resulted from the generation of hydrogen peroxide. Since a number of cells likely to be present at chronic inflammatory sites, such as mononuclear phagocytes, contain enzymatic mechanisms to degrade hydrogen peroxide, the modulatory influence of these cells on the inhibition of $T$ cell function caused by D-penicillamine and copper was examined. Monocytes, whose function was not suppressed by D-penicillamine and copper, were found to protect $T$ lymphocyte responsiveness from the inhibitory effects of either the mixture of D-penicillamine and $\mathrm{CuSO}_{4}$ or of hydrogen peroxide. By contrast, endothelial cells, fibroblasts, or cells obtained from enzyme-digested noninflamed synovium could not protect $T$ cells from the inhibitory effects of D-penicillamine and copper. Protection of $\mathrm{T}$ cells was afforded by means of a heat labile, azidesensitive soluble factor present in lysates of human monocytes. These results indicate that the mechanism whereby D-penicillamine in the presence of copper or ceruloplasmin inhibits $\mathrm{T}$ lymphocyte responsiveness involves the generation of hydrogen peroxide and that other neighboring cells likely to be found within rheumatoid synovium, such as mononuclear phagocytes, are capable of modulating this inhibitory effect.

\section{Introduction}

D-Penicillamine has been demonstrated to be effective in the treatment of rheumatoid arthritis. Moreover, D-penicillamine appears to have the potential to affect the natural history of the disease in some treated patients inducing clinical remissions, decreasing the elevated levels of acute phase reactants and the titers of rheumatoid factor, and slowing the progressive bone 
and cartilage loss characteristic of rheumatoid synovitis (1-5). Despite this well-documented evidence of clinical efficacy, the mechanism by which D-penicillamine achieves this salutory result in rheumatoid arthritis remains unknown.

Although the cause of chronic rheumatoid synovitis remains elusive, it has become clear that immunological mechanisms play an essential role in this process (6). The nature of rheumatoid inflammation therefore suggests the hypothesis that D-penicillamine may be effective because of its capacity to function as an immunosuppressive agent and thereby limit the ongoing immunological reactivity that perpetuates the inflammation.

We have previously presented evidence from in vitro studies suggesting that D-penicillamine may have immunosuppressive capabilities $(7,8)$. Thus, D-penicillamine was shown to inhibit in vitro $\mathrm{T}$ lymphocyte proliferation and the activity of helper $T$ cells in supporting the generation of antibody-forming cells in vitro. Specificity for this inhibitory effect was shown by the finding that D-penicillamine had no apparent effect on the function of monocytes or B lymphocytes. The inhibitory effect of D-penicillamine was markedly accentuated by the presence of copper ions. A variety of other divalent cations were ineffective at increasing the inhibitory action of D-penicillamine on $T$ lymphocyte function.

The aforementioned results supported the view that D-penicillamine may be a selective immunosuppressive agent with the capacity to inhibit $\mathrm{T}$ lymphocyte function specifically. However, the mechanism by which D-penicillamine in the presence of copper ions inhibited $T$ cell activity remained unclear. It was initially thought that complexes between D-penicillamine and copper could form in culture and that these might have heightened suppressive activity perhaps by facilitating copper entry into $\mathrm{T}$ lymphocytes. This interpretation was suggested by the finding that D-penicillamine-copper complexes exhibited antiinflammatory effects in animal models of inflammation, although D-penicillamine itself had only a minimal antiinflammatory effect $(9,10)$. This appeared to be an unlikely explanation, however, since preformed complexes of D-penicillamine and copper were found to have no inhibitory effect on $\mathrm{T}$ cell function (11). Thus, the mechanism by which D-penicillamine and copper suppressed $\mathrm{T}$ lymphocyte activity remained unclear.

The current studies were undertaken, therefore, to examine in greater detail the mechanism of the inhibitory action of $D$ penicillamine and copper ions on $\mathrm{T}$ lymphocyte function. Three specific issues were explored. First, the potential of ceruloplasmin (Cp), ${ }^{1}$ the major copper-containing protein in the serum (12) to facilitate D-penicillamine-mediated inhibition of $T$ lymphocyte function was examined. In support of the in vivo relevance of this in vitro model, it was found that $\mathrm{Cp}$, depleted of nonspecifically bound copper, was comparable to free copper ions in its capacity to promote the inhibition of $\mathrm{T}$ cell function

1. Abbreviations used in this paper: Con A, concanavalin $\mathrm{A}$; $\mathrm{Cp}$, ceruloplasmin; NK, natural killer; PBMC, peripheral blood mononuclear cells; PHA, phytohemagglutinin; SOD, superoxide dismutase. caused by $\mathrm{D}$-penicillamine. The second issue involved a dissection of the mechanism by which the mixture of D-penicillamine and copper or $\mathrm{Cp}$ altered $\mathrm{T}$ cell function. The data support the conclusion that this inhibition resulted from the generation of $\mathrm{H}_{2} \mathrm{O}_{2}$, which had a markedly inhibitory effect on $T$ cell function. Finally, the capacity of additional cells that are likely to be found in rheumatoid synovial tissue to modulate the inhibitory action of D-penicillamine and copper was examined. Monocytes were found to have the capacity to protect $\mathrm{T}$ lymphocytes from the inhibitory effects of both the mixture of D-penicillamine and copper and $\mathrm{H}_{2} \mathrm{O}_{2}$. Protection was afforded by means of a heat-labile, soluble, azide-sensitive mechanism, which most likely resulted from the activity of catalase. These results support the conclusion that D-penicillamine in the presence of copper or $\mathrm{Cp}$ may exert immunosuppressive activity by specifically inhibiting the function of $\mathrm{T}$ lymphocytes. Inhibition resulted from the generation of $\mathrm{H}_{2} \mathrm{O}_{2}$ and could be prevented by neighboring cells of the mononuclear phagocyte series with the capacity to dispose of $\mathrm{H}_{2} \mathrm{O}_{2}$.

\section{Methods}

Cell preparation. Peripheral blood mononuclear cells (PBMC) were obtained from normal adult volunteers by centrifugation of heparinized venous blood on sodium diatrizoate/Ficoll cushions (Isolymph, Gallard Schlesinger Chemical Manufacturing Corp., Carle Place, NY) as previously described $(7,8)$. The cells were washed three times in Hanks' balanced salt solution (HBSS) before culture or further processing. In some experiments, PBMC were incubated in glass petri dishes as previously described (13) to separate them into populations of adherent and nonadherent cells. The latter were harvested, incubated on a second petri dish to remove residual adherent cells and then decanted and suspended in fresh medium. Adherent cells were harvested from the initial petri dish with a rubber policeman and treated with mitomycin C (40 $\mu \mathrm{g} / \mathrm{ml}$, Sigma Chemical Co., St. Louis, MO) for $45 \mathrm{~min}$ at $37^{\circ} \mathrm{C}$, washed extensively, and suspended in fresh medium. The adherent cells contained $85-90 \%$ monocytes as detected by standard criteria (13). A $T$ lymphocyte-enriched population was purified from the nonadherent cells by rosetting the cells with neuraminidase-treated sheep erythrocytes, followed by centrifugation on diatrizoate/Ficoll cushions. The pelleted cells were harvested and further purified by passage over a nylon wool column. The population passing through the column was highly enriched with $\mathrm{T}$ cells (90-95\% neuraminidase sheep erythrocyte rosetting) and deficient in monocytes $(<1 \%)$.

Cell culture for assay of lymphocyte DNA synthesis. Cell cultures were carried out in sterile microtiter plates (Dynatech Laboratories, Inc., Dynatech Corp., Alexandria, VA). Routine cultures were done in triplicate with each well containing $1 \times 10^{5}$ responding cells in $0.2 \mathrm{ml}$ of culture medium RPMI 1640 (Microbiological Associates, Walkersville, $\mathrm{MD})$, supplemented with L-glutamine $(0.3 \mathrm{mg} / \mathrm{ml})$, gentamicin $(10 \mu \mathrm{g} /$ $\mathrm{ml})$, and penicillin $\mathrm{G}(200 \mathrm{U} / \mathrm{ml})$. The medium was further supplemented with $10 \%$ fetal bovine serum (Microbiological Associates). The cells were incubated for 72-96 h with phytohemagglutinin (PHA, $0.5 \mu \mathrm{g} / \mathrm{ml}$ ) or concanavalin A (Con A, $10 \mu \mathrm{g} / \mathrm{ml}$ ) dissolved in HBSS or an equal volume $(20 \mu \mathrm{l})$ of $\mathrm{HBSS}$ as control at $37^{\circ} \mathrm{C}$ in a humidified atmosphere of $5 \% \mathrm{CO}_{2}$ and $95 \%$ air. $18 \mathrm{~h}$ before harvesting, $1 \mu \mathrm{Ci}$ of $\left[{ }^{3} \mathrm{H}\right]$ thymidine (6.7 Ci/mM, New England Nuclear, Boston, MA) was added to each 
well. The cells were harvested onto glass fiber filter paper with a semiautomated microharvesting device, and $\left[{ }^{3} \mathrm{H}\right]$ thymidine incorporation was then determined by liquid scintillation spectroscopy. All data are expressed as the difference in counts per minute between the means of triplicate mitogen stimulated and control cultures $(\Delta \mathrm{cpm})$. In some experiments, data are expressed as percent change from control calculated according to the following formula:

$$
\% \text { change }=\left[\frac{\Delta \mathrm{cpm}_{\mathrm{i}}}{\Delta \mathrm{cpm}_{\mathrm{c}}}-1\right] \times 100
$$

where $\Delta \mathrm{cpm}_{\mathrm{i}}$ equals proliferative response in the presence of a putative inhibitor and $\Delta \mathrm{cpm}_{\mathrm{c}}$ equals proliferative response in control cultures.

Reagents. The following reagents were used: D-penicillamine (Merck Sharp \& Dohme Research Laboratories, Rahway, NJ); cupric sulfate (Mallinckrodt Inc., Science Products Div., St. Louis, MO); $\mathrm{H}_{2} \mathrm{O}_{2}$ (Sigma Chemical Co.); catalase (Sigma Chemical Co. or Worthington Biochemical Corp., Freehold, NJ); concanavalin A (Con A, CalbiochemBehring Corp., American Hoechst Corp., San Diego, CA); superoxide dismutase (SOD) (Sigma Chemical Co.); sodium borohydride (Sigma Chemical Co.); PHA (Burroughs Wellcome \& Co., Greenville, NC). Human $\mathrm{Cp}$ was purified from a commercially available crude preparation (Sigma Chemical Co.) by Sephacryl S-200 chromatography as previously described (14). In some experiments nonspecifically bound copper was additionally removed from this material by passage over Chelex-100 columns as previously described (15).

Preparation of nonlymphoid cells. Umbilical vein endothelial cells and skin fibroblasts were prepared as previously described (16). Endothelial cells were used on the first subpassage while fibroblasts were used after being passed 12 times. Synovium was obtained from patients with degenerative joint disease at the time of total joint replacement. Samples of synovium revealed minimal infiltration with inflammatory cells. Individual synovial cells were obtained by collagenase digestion as previously described (17). Each of these populations was treated with mitomycin $\mathrm{C}$ before use in experiments.

Preincubation experiments. In some experiments, $\mathrm{T}$ cells were suspended in medium $\left(2 \times 10^{6} / \mathrm{ml}\right)$ either alone or with catalase $(50 \mathrm{U} /$ $\mathrm{ml}$ ) or an equal number of autologous monocytes. The cells were then incubated in $17 \times 100$-mm polypropylene tubes for $1 \mathrm{~h}$ at $37^{\circ} \mathrm{C}$ with medium alone or with sodium azide $(1 \mathrm{mM}) \cdot \mathrm{H}_{2} \mathrm{O}_{2}(44 \mu \mathrm{M})$, the mixture of D-penicillamine $(25 \mu \mathrm{g} / \mathrm{ml})$ and $\mathrm{CuSO}_{4}(2 \mu \mathrm{g} / \mathrm{ml})$, or an equal volume of saline was then added to the tubes and they were incubated for an additional hour at $37^{\circ} \mathrm{C}$. Afterward, the cells were washed extensively, suspended in fresh medium without inhibitors, aliquoted into microtiter wells $\left(1 \times 10^{5} \mathrm{~T}\right.$ cells/well), incubated for $72 \mathrm{~h}$ with PHA or Con A as indicated and assayed for $\left[{ }^{3} \mathrm{H}\right]$ thymidine incorporation.

\section{Results}

Cp augments the inhibitory effect of D-penicillamine on mitogeninduced lymphocyte proliferation. It has previously been reported that copper ions markedly enhance the inhibitory effect of D-penicillamine and other thiols on $\mathrm{T}$ lymphocyte proliferation $(7,8)$. Similar results were found in these studies. Thus, D-penicillamine itself had only a modest inhibitory effect on PHA-induced $\left[{ }^{3} \mathrm{H}\right]$ thymidine incorporation (Fig. 1). Similarly, $\mathrm{CuSO}_{4}$ had no significant inhibitory effect. However, when $\mathrm{CuSO}_{4}$ was added to cultures containing D-penicillamine, a markedly enhanced inhibitory effect was noted as has been pre-

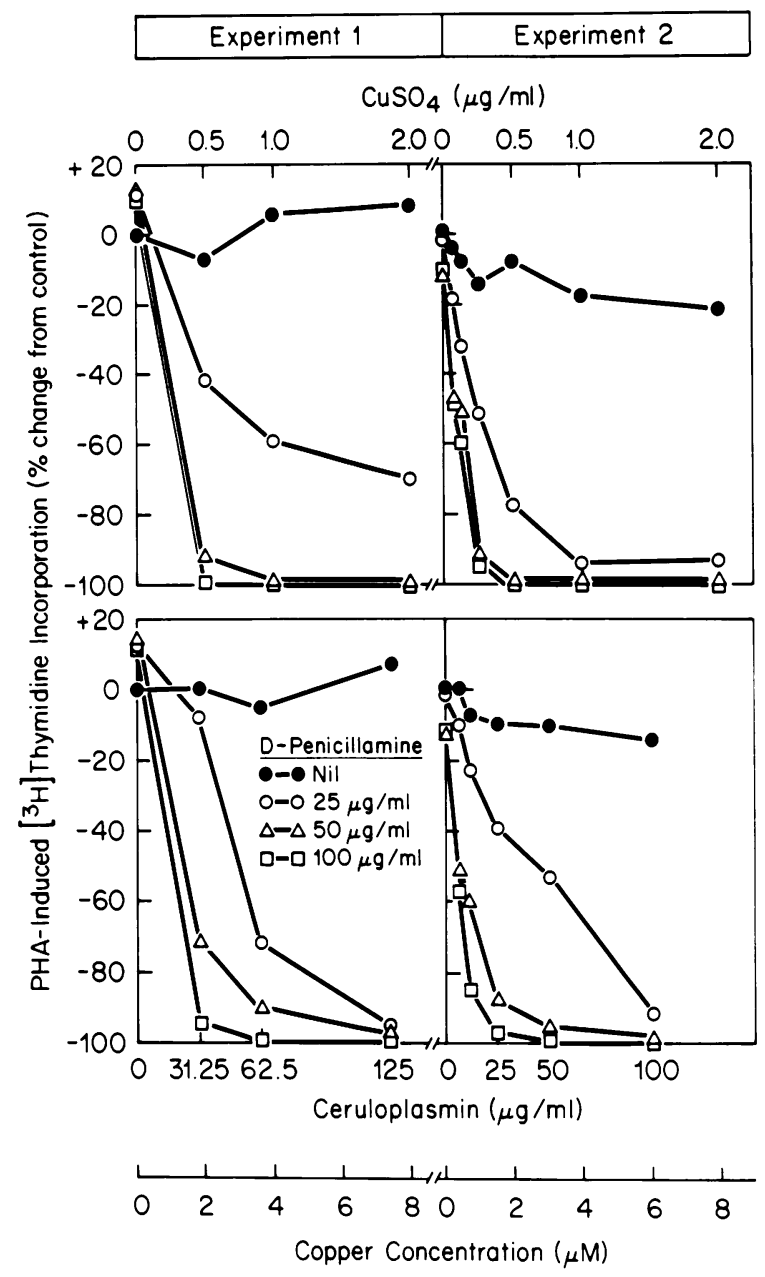

Figure 1. Cp promotes the inhibitory effect of D-penicillamine on mitogen-induced lymphocyte proliferation. Human PBMC were stimulated with PHA in the presence of the indicated concentration of D-penicillamine and with or without various concentrations of $\mathrm{CuSO}_{4}$ or $\mathrm{Cp}$ as indicated. In each circumstance the molarity of copper is indicated.

viously described (7). The capacity of $\mathrm{Cp}$ to substitute for ionic copper in this inhibitory effect was examined. As can be seen in Fig. 1, Cp itself was not inhibitory at the concentrations tested. For reference, it should be noted that serum $\mathrm{Cp}$ concentration in normal individuals is $\sim 300 \mu \mathrm{g} / \mathrm{ml}$ (18). Thus, all of the concentrations used were well within the range anticipated in the serum of normal individuals. When $\mathrm{Cp}$ was added to cultures also containing D-penicillamine, synergistic inhibition of mitogen-induced $\left[{ }^{3} \mathrm{H}\right]$ thymidine incorporation was observed. Of importance, when the concentrations of $\mathrm{CuSO}_{4}$ and $\mathrm{Cp}$ were normalized for copper concentration, $\mathrm{Cp}$ was found to be comparable to $\mathrm{CuSO}_{4}$ in its capacity to promote inhibition in cultures containing D-penicillamine.

To insure that the inhibitory effect of $\mathrm{Cp}$ in the presence of D-penicillamine was not mediated by copper that was nonspe- 
cifically bound to the protein, Chelex-100 column purification of $\mathrm{Cp}$ was carried out. In initial experiments, $\mathrm{CuSO}_{4}$ at a concentration of $10 \mathrm{mg} / \mathrm{ml}$ was passed over the Chelex-100 column. This material was then added to D-penicillamine-containing cultures at a final dilution of 1:10. No inhibitory effect was noted above that owing to the D-penicillamine itself. Thus, the capacity of Chelex-100 to remove ionic copper was clearly demonstrable. In the experiments shown in Table I, both $\mathrm{CuSO}_{4}$ and $\mathrm{Cp}$ were found to augment the inhibitory effect of D-penicillamine on mitogen-induced $\left[{ }^{3} \mathrm{H}\right]$ thymidine incorporation. However, Chelex-100 passage of the $\mathrm{CuSO}_{4}$ removed this capacity, while $\mathrm{Cp}$ retained its activity after passage over Chelex100 columns. These data support the conclusion that the capacity of $\mathrm{Cp}$ to augment D-penicillamine-mediated inhibition of lymphocyte proliferation does not result from copper ions that might be nonspecifically bound by the protein.

Mechanism of the inhibition of $T$ lymphocyte proliferation by D-penicillamine in the presence of copper or $C p$. The approach that was used to discern the mechanism by which the mixture of D-penicillamine and copper inhibited $T$ lymphocyte function was to attempt to prevent the inhibition in a variety of ways. One maneuver that was found to protect $T$ cell mitogen responsiveness partially from the inhibitory effect of D-penicillamine and copper is shown in Fig. 2. Sodium borohydride, a reducing agent, was found to prevent partially the inhibitory effect of the mixture of D-penicillamine and $\mathrm{CuSO}_{4}$. This was especially noteworthy at lower concentrations of D-penicillamine; at higher D-penicillamine concentrations $(100 \mu \mathrm{g} / \mathrm{ml})$, sodium borohydride could not prevent the inhibitory action of the mixture of D-penicillamine and copper. These results suggested that an oxidizing stress, especially that conveyed by oxygen radicals, might be involved in the inhibitory effect of the mixture of D-penicillamine and copper.

To examine this possibility further, a number of enzymes were used with the capacity to degrade certain oxygen radicals. As noted in Fig. 3, SOD had no protective effect whatsoever on the inhibition of $\mathrm{T}$ lymphocyte proliferation caused by the mixture of D-penicillamine and $\mathrm{CuSO}_{4}$. In fact, with higher concentrations of D-penicillamine, inhibition was often augmented by SOD. This augmentation of inhibition by SOD appeared to relate to its copper content (19) and not its enzymatic activity, since the effect was markedly increased after denaturing the enzyme by boiling. In contrast to the lack of protection by SOD, catalase completely reversed the inhibitory effect of Dpenicillamine and $\mathrm{CuSO}_{4}$ at all concentrations of D-penicillamine used (Fig. 4). The effect of catalase required its enzymatic activitiy and was not an action conveyed by some other aspect of the protein as indicated by the finding that boiled catalase, which no longer had enzymatic activity (20), was totally ineffective in preventing the inhibition of lymphocyte proliferation caused by the mixture of D-penicillamine and copper (Table II). Moreover, horseradish peroxidase, an enzyme that utilizes peroxide to catalyze the oxidation of a variety of organic substrates, was also found to protect $\mathrm{T}$ lymphocyte mitogen responsiveness from the inhibitory action of $\mathrm{D}$-penicillamine and $\mathrm{CuSO}_{4}$ (Table III). In experiments not shown in detail, myeloperoxidase $(500 \mathrm{U} / \mathrm{ml})$ was also found to reverse the inhibitory effect of D-penicillamine and copper. These results all support

Table I. Ceruloplasmin-mediated Enhancement of the Inhibitory Action of D-Penicillamine: Lack of Effect of Nonspecifically Associated Copper

\begin{tabular}{|c|c|c|c|c|c|c|}
\hline \multirow[b]{2}{*}{ Expt } & \multicolumn{2}{|c|}{ Addition to culture } & \multicolumn{4}{|c|}{ D-Penicillamine concentration $(\mu \mathrm{g} / \mathrm{ml})$} \\
\hline & $\begin{array}{l}\text { Copper } \\
\text { compound }\end{array}$ & Treatment* & 0 & 25 & 50 & 100 \\
\hline & & & PHA-ind & $d\left[{ }^{3} H\right]$ thymidin & corporation ( $c p$ & $\times\left(0^{-3}\right)$ \\
\hline \multirow[t]{5}{*}{1} & 0 & 0 & $107.1 \pm 1.6$ & $108.7 \pm 5.2$ & $96.2 \pm 2.7$ & $85.2 \pm 3.6$ \\
\hline & $\mathrm{CuSO}_{4}$ & 0 & $73.6 \pm 2.7$ & $44.2 \pm 2.1$ & $11.9 \pm 1.4$ & $1.4 \pm 0.1$ \\
\hline & $\mathrm{CuSO}_{4}$ & Chelex & $100.1 \pm 2.2$ & $114.2 \pm 3.4$ & $98.2 \pm 1.3$ & $83.0 \pm 3.3$ \\
\hline & $\mathrm{Cp}$ & 0 & $81.8 \pm 7.4$ & $58.0 \pm 0.9$ & $21.6 \pm 2.3$ & $0.3 \pm 0.5$ \\
\hline & $\mathrm{Cp}$ & Chelex & $99.3 \pm 3.4$ & $82.4 \pm 1.7$ & $34.2 \pm 1.8$ & $7.3 \pm 0.7$ \\
\hline \multirow[t]{5}{*}{2} & 0 & 0 & $127.8 \pm 8.6$ & $133.0 \pm 4.2$ & $108.8 \pm 3.9$ & $80.3 \pm 7.0$ \\
\hline & $\mathrm{CuSO}_{4}$ & 0 & $121.1 \pm 3.6$ & $71.4 \pm 2.9$ & $35.6 \pm 1.9$ & $2.0 \pm 0.2$ \\
\hline & $\mathrm{CuSO}_{4}$ & Chelex & $118.6 \pm 2.4$ & $118.4 \pm 8.0$ & $90.9 \pm 6.7$ & $66.2 \pm 8.7$ \\
\hline & $\mathrm{Cp}$ & 0 & $129.8 \pm 5.7$ & $84.5 \pm 3.2$ & $43.3 \pm 2.4$ & $0.5 \pm 0.1$ \\
\hline & $\mathrm{Cp}$ & Chelex & $123.8 \pm 1.7$ & $81.5 \pm 11.0$ & $48.6 \pm 3.1$ & $4.7 \pm 1.3$ \\
\hline
\end{tabular}

* $\mathrm{CuSO}_{4}$ or purified $\mathrm{Cp}$ were added directly to culture at the final concentration indicated or suspended in saline at a concentration of $1 \mathrm{mg} / \mathrm{ml}$ and passed over a column of Chelex100 before addition to culture. Final concentrations: $\mathrm{CuSO}_{4}, 2 \mu \mathrm{g} / \mathrm{ml} ; \mathrm{Cp}, 50 \mu \mathrm{g} / \mathrm{ml}$. 


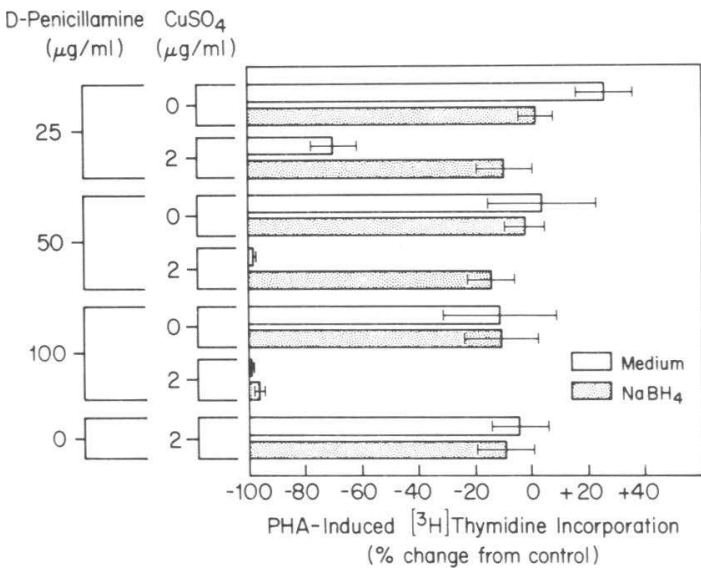

Figure 2. Sodium borohydride partially reverses the inhibitory effect of D-penicillamine and $\mathrm{CuSO}_{4}$. PBMC were cultured with various concentrations of D-penicillamine in the presence or absence of $\mathrm{CuSO}_{4}$. In addition, $\mathrm{NaBH}_{4}(20 \mu \mathrm{g} / \mathrm{ml})$ was added to culture where indicated. Data indicate the mean $( \pm S E M)$ percent change in PHAinduced $\left[{ }^{3} \mathrm{H}\right]$ thymidine incorporation from control cultures containing no inhibitors of three replicate experiments.

the conclusion that the production of $\mathrm{H}_{2} \mathrm{O}_{2}$ is involved in the inhibition of lymphocyte function caused by $\mathrm{D}$-penicillamine and copper.

Experiments were next carried out to confirm that the inhibition caused by D-penicillamine in the presence of $\mathrm{Cp}$ had a comparable mechanism of action. As can be seen in Table IV, the inhibition of lymphocyte responsiveness caused by the mixture of D-penicillamine and either Cp or Chelex-100 columnpassed $\mathrm{Cp}$ was reversed by the addition of catalase. Thus, inhibition of lymphocyte responsiveness caused by D-penicillamine and $\mathrm{Cp}$ appears to be comparable to that caused by D-penicillamine and $\mathrm{CuSO}_{4}$ in that it involves the production of $\mathrm{H}_{2} \mathrm{O}_{2}$.

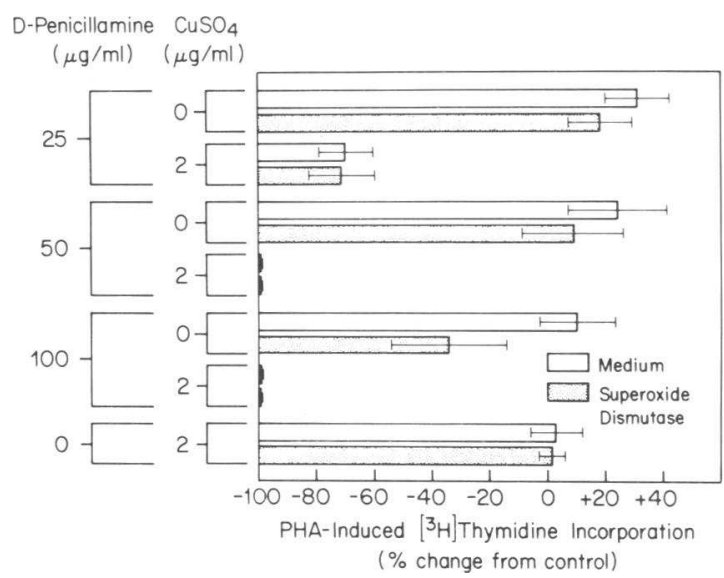

Figure 3. SOD does not reverse the inhibitory effect of Dpenicillamine and $\mathrm{CuSO}_{4}$. SOD was used at a concentration of 50 $\mu \mathrm{g} / \mathrm{ml}$. Data indicate the mean \pm SEM of three replicate experiments.

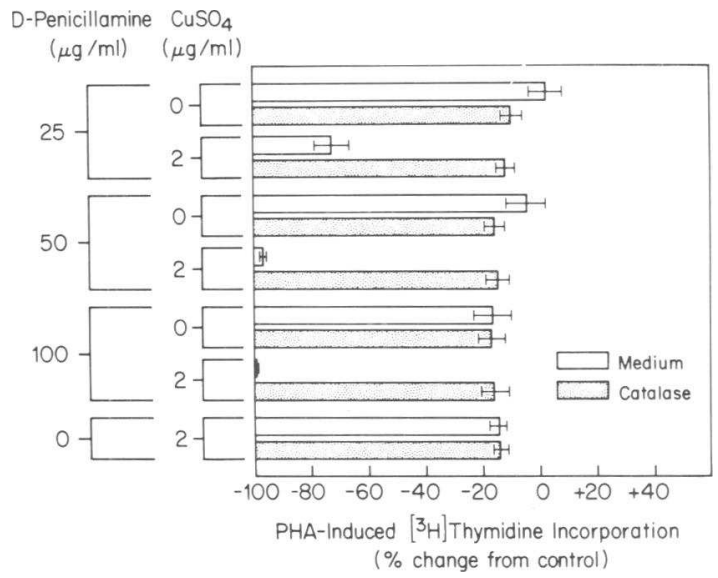

Figure 4. Catalase reverses the inhibitory effect of D-penicillamine and $\mathrm{CuSO}_{4}$. Catalase was used at $500 \mathrm{U} / \mathrm{ml}$. Data indicate the mean \pm SEM of eight replicate experiments.

Monocytes prevent the inhibitory effect of D-penicillamine and copper on mitogen-induced lymphocyte proliferation. Previous experiments demonstrated that the mixture of D-penicillamine and copper had no inhibitory effect on the function of human monocytes $(7,8)$. Experiments had also suggested that purified $\mathrm{T}$ lymphocytes were somewhat more inhibited by the mixture of D-penicillamine and $\mathrm{CuSO}_{4}$ than was a mixed population of PBMC that contained many more monocytes (8). Moreover, as noted above, myeloperoxidase appeared to be able to protect $T$ lymphocytes from the effects of D-penicillamine and copper. Therefore, it was possible that intact monocytes might also protect $\mathrm{T}$ lymphocytes from the inhibitory action of these compounds. To examine this possibility, partially monocyte-depleted T cells were prepared, stimulated with PHA and assayed for $\left[{ }^{3} \mathrm{H}\right]$ thymidine incorporation. As can be seen in Fig. 5, responsiveness of this population was present but diminished compared with that attainable when these cells were co-cultured with mitomycin C-treated monocytes. The effect of the mixture of D-penicillamine and copper or $\mathrm{H}_{2} \mathrm{O}_{2}$ was examined in this system. Both $\mathrm{H}_{2} \mathrm{O}_{2}$ and the mixture of D-penicillamine and copper markedly inhibited $\mathrm{T}$ cell $\left[{ }^{3} \mathrm{H}\right]$ thymidine incorporation. The inhibitory effect of each of these agents was somewhat diminished, especially at the lower concentrations, by the addition of fresh monocytes. Because of the possibility that $T$ cell function might be protected by myeloperoxidase present in fresh monocytes, the monocytes were aged for $48 \mathrm{~h}$ before being co-cultured with $\mathrm{T}$ cells. This was done because it has previously been shown that monocytes rapidly lose myeloperoxidase activity with in vitro incubation (21). As shown in Fig. 5, aged monocytes that lacked myeloperoxidase were not less effective than fresh monocytes at protecting $T$ cells from these inhibitors, but rather they were more effective than fresh monocytes. This was especially noted with the higher concentrations of either $\mathrm{H}_{2} \mathrm{O}_{2}$ or D-penicillamine and copper. Whereas the inhibitory effects of the higher concentrations of these agents 
Table II. Inhibition of Mitogen-induced Lymphocyte DNA Synthesis by D-Penicillamine and $\mathrm{CuSO}_{4}$ : Prevention by Catalase but Not Boiled Catalase

\begin{tabular}{|c|c|c|c|}
\hline \multirow[b]{2}{*}{ Addition* } & \multicolumn{3}{|c|}{ PHA-induced lymphocyte DNA synthesis } \\
\hline & Medium & Catalaseł & $\begin{array}{l}\text { Boiled } \\
\text { catalase } \neq\end{array}$ \\
\hline & \multicolumn{3}{|c|}{$\left[{ }^{3} H\right]$ Thymidine incorporation, $\Delta c p m \times 10^{-3} \S$} \\
\hline None & $73.7 \pm 6.6$ & $65.3 \pm 5.9$ & $66.3 \pm 6.8$ \\
\hline D-Penicillamine & $63.6 \pm 9.3$ & $60.7 \pm 9.3$ & $57.7 \pm 4.4$ \\
\hline $\mathrm{CuSO}_{4}$ & $66.3 \pm 5.9$ & $63.4 \pm 5.0$ & $69.2 \pm 7.2$ \\
\hline \multicolumn{4}{|c|}{ D-Penicillamine plus } \\
\hline $\mathrm{CuSO}_{4}$ & $0.2 \pm 0.1$ & $61.1 \pm 5.2$ & $0.1 \pm 0.0$ \\
\hline
\end{tabular}

*D-Penicillamine, $100 \mu \mathrm{g} / \mathrm{ml} ; \mathrm{CuSO}_{4}, 2 \mu \mathrm{g} / \mathrm{ml}$.

$\ddagger 500 \mathrm{U} / \mathrm{ml}$ before boiling.

$\S$ Data represent mean \pm SEM, $n=3$.

were only marginally reversed by fresh monocytes, responsiveness was protected to a much greater degree by aged monocytes.

The question of whether monocytes, but not other cells likely to be present in synovial tissue, were unique in their capacity to protect $T$ cells from the inhibitory effects of the mixture of D-penicillamine and $\mathrm{CuSO}_{4}$ was next examined. Endothelial cells, fibroblasts, and a mixed cell population obtained by collagenase digestion of noninflamed synovium were tested for this activity. As can be seen in Table V, each population had the capacity to augment mitogen responses of $T$ cells in control cultures. Again, the mixture of D-penicillamine and $\mathrm{CuSO}_{4}$ markedly inhibited mitogen-induced $\mathrm{T}$ cell $\left[{ }^{3} \mathrm{H}\right]$ thymidine incorporation. The degree of inhibition was substantially reduced by monocytes, but not by endothelial cells, fibroblasts, or synovial cells. These results suggest that of the cell types likely to be present in rheumatoid synovial tissue, monocytes appear to be unique in their capacity to protect $T$ cells from the inhibitory effects of D-penicillamine and copper.

Experiments were next carried out to determine whether viable monocytes were necessary to protect $\mathrm{T}$ lymphocytes from the inhibitory action of D-penicillamine and $\mathrm{CuSO}_{4}$. In these expe.iments, $\mathrm{T}$ cells were cultured alone or in the presence of fresh control monocytes or heat-killed monocytes. As can be seen in Table VI, $\mathrm{T}$ cells were quite sensitive to the inhibitory effects of the mixture of D-penicillamine and copper or $\mathrm{H}_{2} \mathrm{O}_{2}$. When $\mathrm{T}$ cells were cultured with control monocytes in the absence of inhibitors, the degree of mitogen-induced $\left[{ }^{3} \mathrm{H}\right]$ thymidine incorporation was much greater than that observed in cultures containing $T$ cells alone. Moreover, the inhibitory effects of the mixture of D-penicillamine and copper were greatly mitigated by the addition of control monocytes as has been seen previously. This was particularly noteworthy with the lower concentration of D-penicillamine. Similarly, the inhibitory effect of $\mathrm{H}_{2} \mathrm{O}_{2}$ was reversed by co-culture with control monocytes. By contrast, heat-killed monocytes were less effective at protecting $T$ cells from the inhibitory effects of these reagents, although some protection appeared to be conveyed.

These results suggested that viable monocytes were necessary to protect $\mathrm{T}$ cells from the inhibitory action of $\mathrm{D}$-penicillamine and copper or $\mathrm{H}_{2} \mathrm{O}_{2}$. Since a number of the potential enzymes that could mediate this protection such as catalase (20) or glutathione peroxidase (22) are heat labile, however, it remained possible that the heat treatment had just denatured these enzymes and that viable monocytes were not required. To examine this possibility, experiments with sonicated monocytes were next carried out. As can be seen in Table VII, intact monocytes or sonicates of monocytes augmented mitogen responsiveness of $\mathrm{T}$ cells and prevented the inhibition caused by D-penicillamine and copper or $\mathrm{H}_{2} \mathrm{O}_{2}$. Heated monocytes or heated sonicates of monocytes also augmented responsiveness, but were unable to

Table III. Inhibition of Mitogen-induced Lymphocyte DNA Synthesis by D-Penicillamine and $\mathrm{CuSO}_{4}$ : Reversal by Catalase and Horseradish Peroxidase

\begin{tabular}{|c|c|c|c|c|}
\hline \multirow[b]{2}{*}{ Expt } & \multirow[b]{2}{*}{ Addition to culture* } & \multicolumn{3}{|c|}{ PHA-induced lymphocyte DNA synthesis } \\
\hline & & Medium & Catalaseł & HRPOS \\
\hline & & $\Delta c p m \times 10^{-3}$ & $\Delta c p m \times 10^{-3}$ & $\Delta c p m \times 10^{-3}$ \\
\hline \multirow[t]{2}{*}{1} & Medium & $88.0 \pm 4.8$ & $76.6 \pm 7.4$ & $77.3 \pm 8.4$ \\
\hline & D-Penicillamine plus $\mathrm{CuSO}_{4}$ & $0.5 \pm 0.0$ & $73.7 \pm 6.4$ & $73.9 \pm 3.8$ \\
\hline \multirow[t]{2}{*}{2} & Medium & $214.3 \pm 6.8$ & $202.5 \pm 7.8$ & $173.5 \pm 12.7$ \\
\hline & D-Penicillamine plus $\mathrm{CuSO}_{4}$ & $0.3 \pm 0.0$ & $193.9 \pm 7.4$ & $218.3 \pm 8.3$ \\
\hline \multirow[t]{2}{*}{3} & Medium & $40.0 \pm 0.8$ & $32.0 \pm 1.2$ & $34.6 \pm 1.4$ \\
\hline & D-Penicillamine plus $\mathrm{CuSO}_{4}$ & $0.1 \pm 0.0$ & $39.6 \pm 0.6$ & $36.7 \pm 0.9$ \\
\hline
\end{tabular}

* D-Penicillamine, $100 \mu \mathrm{g} / \mathrm{ml} ; \mathrm{CuSO}_{4}, 2 \mu \mathrm{g} / \mathrm{ml}$.

$\mp 500 \mathrm{U} / \mathrm{ml}$.

$\S$ Horseradish peroxidase (HRPO), $280 \mathrm{U} / \mathrm{ml}$ 
Table IV. Catalase Prevents the Inhibition of Mitogen-induced Lymphocyte DNA Synthesis Caused by D-Penicillamine and $C p$

\begin{tabular}{|c|c|c|c|c|c|}
\hline \multicolumn{2}{|l|}{ Addition to culture* } & \multicolumn{4}{|c|}{ PHA-induced $\left[{ }^{3} \mathrm{H}\right]$ thymidine incorporation } \\
\hline Inhibitor & Catalase & Expt 1 & Expt 2 & Expt 3 & Expt 4 \\
\hline & & \multicolumn{4}{|c|}{$\%$ change from control } \\
\hline None & + & -6.0 & +6.0 & -6.5 & +13.8 \\
\hline D-Penicillamine plus Cp & 0 & -99.9 & -98.5 & -99.0 & -75.6 \\
\hline D-Penicillamine plus $\mathrm{Cp}$ & + & -16.0 & -16.8 & -8.9 & -12.7 \\
\hline D-Penicillamine plus Chelex Cp & 0 & ND & -96.3 & -90.3 & -66.4 \\
\hline D-Penicillamine plus Chelex $\mathrm{Cp}$ & + & ND & -19.8 & +2.0 & -7.8 \\
\hline
\end{tabular}

* D-Penicillamine, $50 \mu \mathrm{g} / \mathrm{ml}$; Cp, $100 \mu \mathrm{g} / \mathrm{ml}$; catalase, $500 \mathrm{U} / \mathrm{ml}$.

protect $\mathrm{T}$ cells from the inhibitory effects of $\mathrm{D}$-penicillamine and $\mathrm{CuSO}_{4}$ or $\mathrm{H}_{2} \mathrm{O}_{2}$.

Finally, experiments were carried out to examine the protection from the inhibitory effect of D-penicillamine and copper or $\mathrm{H}_{2} \mathrm{O}_{2}$ afforded by sonicates of monocytes. As seen in Table VIII, sonicated monocytes were again able to augment the responsiveness in these markedly monocyte-depleted cultures and to protect $T$ cells from the inhibitory action of either the mixture of D-penicillamine and $\mathrm{CuSO}_{4}$ or $\mathrm{H}_{2} \mathrm{O}_{2}$. Moreover, both these activities were retained after the sonicated monocytes were passed through a $0.45-\mu \mathrm{m}$ filter. By contrast, sonicates of $T$ cells were able neither to augment mitogen responsiveness in $\mathrm{T}$ cell cultures or to protect $\mathrm{T}$ cells from the inhibitory action of D-penicillamine and copper or $\mathrm{H}_{2} \mathrm{O}_{2}$. Catalase protected $\mathrm{T}$ cells from the in-

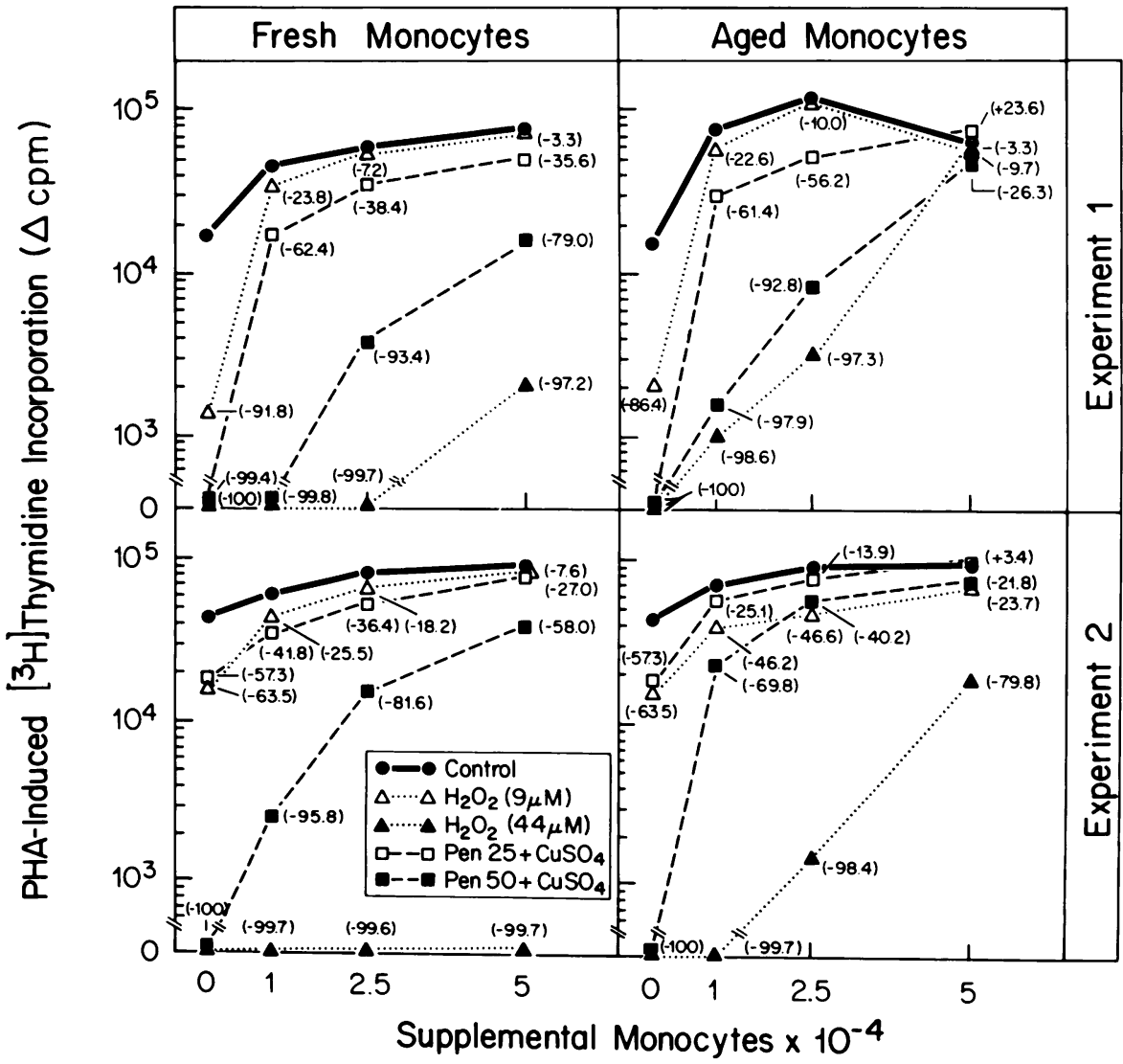

Figure 5. Monocytes protect against the inhibitory effects of D-penicillamine and $\mathrm{CuSO}_{4}$ or $\mathrm{H}_{2} \mathrm{O}_{2}$. T cells were co-cultured alone or with various numbers of autologous mitomycin-C treated monocytes. The monocytes were either fresh or had been preincubated for $48 \mathrm{~h}$ before culture with $\mathrm{T}$ cells. The aged monocytes were markedly deficient in their content of myeloperoxidase as indicated by staining for peroxidase activity (Histozyme peroxidase indicator reagent, Sigma Chemical Co.). In addition, the cultures contained $\mathrm{H}_{2} \mathrm{O}_{2}$ or mixtures of D-penicillamine and $\mathrm{CuSO}_{4}$ $(2 \mu \mathrm{g} / \mathrm{ml})$ as indicated. After a $72-\mathrm{h}$ incubation with $\mathrm{PHA},\left[{ }^{3} \mathrm{H}\right]$ thymidine incorporation was determined. Numbers in parentheses indicate percent change from control responses. 
Table V. D-Penicillamine and CuSO,-mediated Inhibition of Mitogen-induced Lymphocyte Responsiveness: Specificity of the Protection Afforded by Monocytes

\begin{tabular}{lrc}
\hline & PHA-induced $\left[{ }^{3} \mathrm{H}\right]$ thymidine incorporation \\
\cline { 2 - 3 } Addition to culture* & Control & $\begin{array}{c}\text { D-Penicillamine } \\
\text { plus CuSO } \$\end{array}$ \\
\hline & \multicolumn{3}{c}{$\left[{ }^{3} H\right]$ Thymidine } \\
Noncorporation, $c p m \times 10^{-3}$ \\
Monocytes & $36.1 \pm 1.8$ & $0.5 \pm 0.0$ \\
Endothelial cells & $80.9 \pm 3.0$ & $20.9 \pm 3.2$ \\
Fibroblasts & $104.4 \pm 5.3$ & $0.8 \pm 0.0$ \\
Synovial cells & $60.9 \pm 4.8$ & $3.0 \pm 0.5$ \\
& $74.0 \pm 2.8$ & $3.9 \pm 0.3$ \\
\hline
\end{tabular}

* $1 \times 10^{5} \mathrm{~T}$ cells were cultured alone or with $5 \times 10^{4}$ mitomycin C. treated monocytes, endothelial cells, fibroblasts, or synovial cells. $\ddagger$ Penicillamine, $50 \mu \mathrm{g} / \mathrm{ml} ; \mathrm{CuSO}_{4}, 2 \mu \mathrm{g} / \mathrm{ml}$.

hibitory effects of D-penicillamine and $\mathrm{CuSO}_{4}$ or $\mathrm{H}_{2} \mathrm{O}_{2}$ but did not augment responses significantly in control cultures.

In summary, these results indicate that fresh or aged monocytes are able to protect $\mathrm{T}$ lymphocytes from the inhibitory action of either the mixture of D-penicillamine and copper or $\mathrm{H}_{2} \mathrm{O}_{2}$ by a heat-labile soluble material found in filtrates of sonicated monocytes, and that intact viable monocytes themselves are not necessary to carry out this activity.

Monocytes protect $T$ cells from the inhibitory action of $D$ penicillamine and $\mathrm{CuSO}_{4}$ by a sodium azide-sensitive mechanism. Monocytes contain at least two enzymatic mechanisms that could protect $\mathrm{T}$ cells from the inhibitory effects of the mixture of D-penicillamine and $\mathrm{CuSO}_{4}$ or of $\mathrm{H}_{2} \mathrm{O}_{2}$. These are catalase (20) and glutathione peroxidase (22). To examine which of these enzymes was involved, advantage was taken of the fact that catalase, a heme-containing enzyme, is inhibited by sodium azide (21), whereas glutathione peroxidase, a selenium-containing enzyme, is not (23). Sodium azide, however, inhibits a variety of other heme-containing enzymes including those involved in oxidative metabolism and thus cannot be directly added to culture without causing inhibition of mitogen-induced lymphocyte responses. However, since only a brief exposure to D-penicillamine and $\mathrm{CuSO}_{4}$ is required to inhibit subsequent $T$ cell responses to mitogen $(7,8)$ and the effects of sodium azide are reversible, a preincubation protocol could be used to examine the nature of the protection afforded by monocytes. As can be seen in Table IX, a 1-h exposure of T lymphocytes to sodium azide ( $1 \mathrm{mM}$ ) had no significant effect on their subsequent mitogen responsiveness. By contrast, a 1-h exposure to the mixture of D-penicillamine and $\mathrm{CuSO}_{4}$ or $\mathrm{H}_{2} \mathrm{O}_{2}$ completely inhibited their capacity to respond to mitogens. The inclusion of catalase in the preincubation mixture protected $T$ cells from this inhibition such that they were able to respond to mitogens on subsequent culture. As anticipated, sodium azide completely abrogated the catalase-mediated protection of $\mathrm{T}$ cell function. Monocytes also protected $\mathrm{T}$ cells from inhibition by the mixture of D-penicillamine and $\mathrm{CuSO}_{4}$ (Table IX, expt 2). The protective effect of monocytes was largely overcome by sodium azide. Thus, the protection of $T$ cells from the injurious effects of $\mathrm{H}_{2} \mathrm{O}_{2}$ afforded by monocytes is predominantly the result of the activity of a heme-containing enzyme, and therefore is likely to be accounted for by catalase.

Table VI. D-Penicillamine and CuSO,-mediated Inhibition of Mitogen-induced Lymphocyte Responsiveness: Protection by Monocytes but Not Heat-killed Monocytes

\begin{tabular}{|c|c|c|c|}
\hline \multirow[b]{2}{*}{ Inhibitor } & \multicolumn{3}{|c|}{ Addition to $\mathrm{T}$ cell cultures* } \\
\hline & Medium & Monocytes & Heated Mø \\
\hline & \multicolumn{3}{|c|}{ PHA-induced $\left[{ }^{3} H\right]$ thymidine incorporation, cpm $\times 10^{-3}$} \\
\hline None & $21.5 \pm 1.6$ & $38.7 \pm 1.3$ & $22.3 \pm 1.3$ \\
\hline $\begin{array}{l}\text { D-Penicillamine }(25 \mu \mathrm{g} / \mathrm{ml}) \\
\text { plus } \mathrm{CuSO}_{4}\end{array}$ & $\begin{array}{l}2.0 \pm 0.2 \\
(-90.6) \ddagger\end{array}$ & $\begin{array}{l}27.2 \pm 1.5 \\
(-29.6)\end{array}$ & $\begin{array}{l}8.9 \pm 0.7 \\
(-60.1)\end{array}$ \\
\hline $\begin{array}{l}\text { D-Penicillamine }(50 \mu \mathrm{g} / \mathrm{ml}) \\
\text { plus } \mathrm{CuSO}_{4}\end{array}$ & $\begin{array}{l}0.0 \pm 0.0 \\
(-100)\end{array}$ & $\begin{array}{l}10.4 \pm 1.2 \\
(-73.2)\end{array}$ & $\begin{array}{l}0.1 \pm 0.0 \\
(-99.6)\end{array}$ \\
\hline $\mathrm{H}_{2} \mathrm{O}_{2}(9 \mu \mathrm{M})$ & $\begin{array}{l}8.2 \pm 2.3 \\
(-62.1)\end{array}$ & $\begin{array}{c}35.1 \pm 2.5 \\
(-9.1)\end{array}$ & $\begin{array}{l}17.2 \pm 0.9 \\
(-22.9)\end{array}$ \\
\hline
\end{tabular}

$* 1 \times 10^{5} \mathrm{~T}$ cells were cultured alone or with $5 \times 10^{4}$ control monocytes $(\mathrm{Mø})$ or $5 \times 10^{4}$ heat-treated $\left(60^{\circ} \mathrm{C}\right.$ for $\left.45 \mathrm{~min}\right) \mathrm{Mø}$. Heat-treated Mø were uniformly nonviable when assayed by staining with fluorescein diacetate and ethidium bromide. ¥ Terms in parentheses indicate percent change from controls without inhibitors. 
Table VII. D-Penicillamine and CuSO,-mediated Inhibition of Mitogen-induced Lymphocyte Responsiveness: Protection by Monocytes and Moncyte Lysates

\begin{tabular}{|c|c|c|c|c|c|}
\hline \multirow[b]{2}{*}{ Inhibitorł } & \multicolumn{5}{|c|}{ Addition to $\mathrm{T}$ lymphocyte cultures* } \\
\hline & Medium & Monocytes & $\begin{array}{l}\text { Heated } \\
\text { Mø }\end{array}$ & $\begin{array}{l}\text { Sonicated } \\
\text { Mø }\end{array}$ & $\begin{array}{l}\text { Sonicated and } \\
\text { heated } \mathrm{M}_{\boldsymbol{\theta}}\end{array}$ \\
\hline & \multicolumn{5}{|c|}{ PHA-induced $\left[{ }^{3} H\right]$ thymidine incorporation, $\mathrm{cpm} \times 10^{-3}$} \\
\hline None & $11.0 \pm 1.2$ & $36.8 \pm 0.4$ & $26.8 \pm 0.8$ & $18.3 \pm 1.6$ & $13.6 \pm 3.6$ \\
\hline $\begin{array}{l}\text { D-Penicillamine plus } \\
\mathrm{CuSO}_{4}\end{array}$ & $\begin{array}{r}0.1 \pm 0.0 \\
(-99.6) \S\end{array}$ & $\begin{array}{l}19.1 \pm 1.5 \\
(-48.1)\end{array}$ & $\begin{array}{l}0.2 \pm 0.0 \\
(-99.2)\end{array}$ & $\begin{array}{l}14.3 \pm 1.6 \\
(-21.9)\end{array}$ & $\begin{array}{l}0.3 \pm 0.0 \\
(-97.9)\end{array}$ \\
\hline $\mathrm{H}_{2} \mathrm{O}_{2}$ & $\begin{array}{l}4.8 \pm 0.3 \\
(-56.1)\end{array}$ & $\begin{array}{l}35.7 \pm 1.7 \\
(-3.0)\end{array}$ & $\begin{array}{l}11.6 \pm 1.4 \\
(-56.7)\end{array}$ & $\begin{array}{l}20.4 \pm 2.1 \\
(+11.2)\end{array}$ & $\begin{array}{l}7.4 \pm 0.9 \\
(-45.4)\end{array}$ \\
\hline
\end{tabular}

$* 1 \times 10^{5} \mathrm{~T}$ cells were cultured alone or with $5 \times 10^{4}$ control monocytes $(\mathrm{Mø})$, heat-treated $\left(60^{\circ} \mathrm{C}\right.$ for $\left.45 \mathrm{~min}\right) \mathrm{Mø}$, sonicated Mø, or sonicated and heated Mø. Heat-treated Mø were uniformly nonviable when assayed by staining with fluorescein diacetate and ethidium bromide. No intact cells were seen in the sonicated preparations.

‡ D-Penicillamine, $25 \mu \mathrm{g} / \mathrm{ml} ; \mathrm{CuSO}_{4}, 2 \mu \mathrm{g} / \mathrm{ml} ; \mathrm{H}_{2} \mathrm{O}_{2}, 9 \mu \mathrm{M}$.

$\S$ Terms in parentheses indicate percent change from controls without inhibitors.

\section{Discussion}

A number of clinical trials have established that D-penicillamine is effective in the treatment of rheumatoid arthritis (1-5). Despite the clinical demonstration of efficacy, the means by which Dpenicillamine suppresses rheumatoid inflammation has not yet been clearly elucidated. Although the etiology of rheumatoid arthritis remains elusive, it has become clear that immunological processes play a major role in perpetuating the ongoing inflammatory process $(6)$. Thus, therapeutic agents with the capability of controlling this chronic inflammatory process may be effective by virtue of their activity as immunosuppressive drugs. Using in vitro techniques, we have previously demonstrated that a number of the remission-inducing drugs such as gold compounds (24), chloroquine $(25)$, and D-penicillamine $(7,8)$ have the capacity to act as immunosuppressive agents.

Previous studies have indicated that D-penicillamine in the presence of copper ions selectively inhibits $T$ lymphocyte function with no concomitant alteration of B cell or monocyte function $(7,8)$. However, the mechanism of this inhibition remained

Table VIII. D-Penicillamine- and $\mathrm{CuSO}_{4}$-mediated Inhibition of Mitogen-induced Lymphocyte Responsiveness: Protection by Monocyte Lysates but Not T Cell Lysates

\begin{tabular}{|c|c|c|c|c|c|c|}
\hline \multirow[b]{2}{*}{ Inhibitorł } & \multicolumn{6}{|c|}{ Addition to $\mathrm{T}$ cell cultures* } \\
\hline & Medium & Mø & $\begin{array}{l}\text { Sonicated } \\
\text { Mø }\end{array}$ & $\begin{array}{l}\text { Filtrates of } \\
\text { sonicated Me }\end{array}$ & $\begin{array}{l}\text { Sonicated } \\
\text { T cells }\end{array}$ & Catalase \\
\hline & \multicolumn{6}{|c|}{ PHA-induced $\left[{ }^{3} H\right]$ thymidine incorporation, cpm $\times 10^{-3}$} \\
\hline None & $5.5 \pm 0.3$ & $40.0 \pm 3.2$ & $16.4 \pm 0.4$ & $17.7 \pm 1.7$ & $3.6 \pm 0.2$ & $7.9 \pm 1.1$ \\
\hline $\begin{array}{l}\text { D-Penicillamine plus } \\
\mathrm{CuSO}_{4}\end{array}$ & $\begin{array}{l}1.0 \pm 0.0 \\
(-81.4) \S\end{array}$ & $\begin{array}{l}21.1 \pm 1.3 \\
(-47.1)\end{array}$ & $\begin{array}{l}8.3 \pm 0.3 \\
(-49.6)\end{array}$ & $\begin{array}{l}9.3 \pm 0.4 \\
(-47.4)\end{array}$ & $\begin{array}{l}0.5 \pm 0.1 \\
(-87.1)\end{array}$ & $\begin{array}{l}4.8 \pm 0.2 \\
(-39.2)\end{array}$ \\
\hline $\mathrm{H}_{2} \mathrm{O}_{2}$ & $\begin{array}{l}1.2 \pm 0.0 \\
(-79.1)\end{array}$ & $\begin{array}{c}38.4 \pm 0.7 \\
(-4.0)\end{array}$ & $\begin{array}{c}14.8 \pm 0.6 \\
(-9.8)\end{array}$ & $\begin{array}{l}15.4 \pm 1.4 \\
(-13.0)\end{array}$ & $\begin{array}{l}0.8 \pm 0.1 \\
(-77.9)\end{array}$ & $\begin{array}{l}6.9 \pm 0.7 \\
(-13.0)\end{array}$ \\
\hline
\end{tabular}

$* 1 \times 10^{5} \mathrm{~T}$ cells were cultured alone or with $5 \times 10^{4}$ control monocytes $(\mathrm{M} \emptyset), 5 \times 10^{4}$ sonicated $\mathrm{Mø}$, or $5 \times 10^{4}$ sonicated T cells. No intact cells were seen in the sonicated preparations. In addition, sonicated Mø were passed through a $0.45-\mu \mathrm{m}$ filter and a volume of filtrate equivalent to that obtained from $5 \times 10^{4}$ sonicated $\mathrm{Mø}$ was added to culture. Finally, culture were also supplemented with catalase $(500 \mathrm{U} / \mathrm{ml})$.

‡ D-Penicillamine, $25 \mu \mathrm{g} / \mathrm{ml} ; \mathrm{CuSO}_{4}, 2 \mu \mathrm{g} / \mathrm{ml} ; \mathrm{H}_{2} \mathrm{O}_{2}, 9 \mu \mathrm{M}$.

$\S$ Terms in parentheses indicate percent change from control without inhibitors. 
Table IX. Monocyte-mediated Protection of T Cells from Inhibition by D-Penicillamine and $\mathrm{CuSO}_{4}$ : Reversal by Sodium Azide

\begin{tabular}{|c|c|c|c|c|c|}
\hline \multirow[b]{2}{*}{ Expt } & \multicolumn{3}{|c|}{ Preincubation* } & \multicolumn{2}{|c|}{$\begin{array}{l}\mathrm{T} \text { cell }\left[{ }^{3} \mathrm{H}\right] \text { thymidine } \\
\text { incorporation }\end{array}$} \\
\hline & Cells & Azide & Inhibitor & PHA & Con A \\
\hline & & & & $\mathrm{cpm} \times 10^{-3}$ & $c p m \times 10^{-3}$ \\
\hline \multirow[t]{12}{*}{1} & $T$ cells & 0 & None & $59.9 \pm 3.5$ & $2.9 \pm 0.2$ \\
\hline & & + & & $47.7 \pm 5.1$ & $3.1 \pm 0.3$ \\
\hline & & 0 & $\mathrm{H}_{2} \mathrm{O}_{2}$ & $0.0 \pm 0.0$ & $0.3 \pm 0.1$ \\
\hline & & + & & $0.2 \pm 0.1$ & $0.3 \pm 0.1$ \\
\hline & & 0 & Pen plus $\mathrm{CuSO}_{4}$ & $0.1 \pm 0.0$ & $0.4 \pm 0.0$ \\
\hline & & + & & $0.2 \pm 0.0$ & $0.5 \pm 0.2$ \\
\hline & $\mathrm{T}$ cells plus catalase & 0 & None & $57.2 \pm 2.1$ & $5.0 \pm 0.3$ \\
\hline & & + & & $53.7 \pm 2.7$ & $5.4 \pm 0.7$ \\
\hline & & 0 & $\mathrm{H}_{2} \mathrm{O}_{2}$ & $39.4 \pm 1.8$ & $4.4 \pm 0.8$ \\
\hline & & + & & $0.4 \pm 0.1$ & $1.2 \pm 0.2$ \\
\hline & & 0 & Pen plus $\mathrm{CuSO}_{4}$ & $49.2 \pm 1.9$ & $5.0 \pm 0.3$ \\
\hline & & + & & $0.2 \pm 0.1$ & $0.9 \pm 0.0$ \\
\hline \multirow[t]{9}{*}{2} & $\mathrm{~T}$ cells & 0 & None & $32.0 \pm 0.1$ & $8.3 \pm 0.3$ \\
\hline & & + & & $25.1 \pm 2.5$ & $6.5 \pm 0.8$ \\
\hline & & 0 & Pen plus $\mathrm{CuSO}_{4}$ & $0.3 \pm 0.1$ & $0.1 \pm 0.1$ \\
\hline & & + & & $0.1 \pm 0.0$ & $0.1 \pm 0.0$ \\
\hline & $\mathrm{T}$ cells plus & & & & \\
\hline & monocytes & 0 & None & $65.0 \pm 5.4$ & $61.8 \pm 1.9$ \\
\hline & & + & & $66.9 \pm 6.4$ & $65.1 \pm 3.5$ \\
\hline & & 0 & Pen plus $\mathrm{CuSO}_{4}$ & $41.5 \pm 2.2$ & $41.8 \pm 1.8$ \\
\hline & & + & & $4.4 \pm 0.2$ & $2.3 \pm 0.1$ \\
\hline
\end{tabular}

Pen, D-penicillamine.

* $\mathrm{T}$ cells suspended in medium with or without catalase or an equal number of monocytes were incubated for $1 \mathrm{~h}$ at $37^{\circ} \mathrm{C}$ with medium alone or with sodium azide $(1 \mathrm{mM}) . \mathrm{H}_{2} \mathrm{O}_{2}(44 \mu \mathrm{M})$, the mixture of Dpenicillamine $(25 \mu \mathrm{g} / \mathrm{ml})$ and $\mathrm{CuSO}_{4}(2 \mu \mathrm{g} / \mathrm{ml})$, or an equal volume of saline was then added to the tubes and they were incubated for an additional hour at $37^{\circ} \mathrm{C}$. Afterward, the cells were washed, suspended in fresh medium without inhibitors, incubated for $72 \mathrm{~h}$ with PHA or Con A as indicated and assayed for $\left[{ }^{3} \mathrm{H}\right]$ thymidine incorporation.

to be detailed. Studies carried out heretofore have come to the conclusion that copper is uniquely able to augment the inhibition of $T$ cell function caused by D-penicillamine (7). A number of other divalent cations were unable to substitute for copper in promoting this inhibition. Since the vast majority of copper in serum and synovial fluid exists not as free copper, but as an integral part of the $\mathrm{Cp}$ molecule (12), it was of interest to examine whether or not $\mathrm{Cp}$ could substitute for ionic copper in promoting the inhibitory effect of D-penicillamine.

$\mathrm{Cp}$ is an $\alpha$-2-glycoprotein with a molecular mass of 132,000 D containing six copper atoms per molecule (26). Cp accounts for $>95 \%$ of the circulating copper in normal mammals (12). Although its principal activity remains in dispute, a number of actions of the $\mathrm{Cp}$ molecule have been described. Thus, $\mathrm{Cp}$ possesses significant oxidase activity directed at a variety of substrates
(26). In addition, it can function as an antioxidant (27) and as a scavenger of the superoxide anion radical (14). Recent work has also suggested that $\mathrm{Cp}$ may catalyze the oxidation of various thiol-containing molecules with the release of a variety of oxygen radicals (28-30). The data presented here indicate that $\mathrm{Cp}$ can also augment the inhibitory effect of $\mathrm{D}$-penicillamine on $\mathrm{T}$ cell function as effectively as $\mathrm{CuSO}_{4}$ by promoting the generation of $\mathrm{H}_{2} \mathrm{O}_{2}$. Of importance, inhibition of lymphocyte responsiveness was seen with concentrations of $\mathrm{Cp}$ well within those anticipated to be found in the serum or synovial fluid of patients with rheumatoid arthritis $(18,31)$.

The mechanism by which D-penicillamine and copper or $\mathrm{Cp}$ inhibited $\mathrm{T}$ lymphocyte function was found to involve the generation of $\mathrm{H}_{2} \mathrm{O}_{2}$. This conclusion was based upon a number of observations. First, inhibition was completely prevented by 
the addition to culture of catalase but not boiled catalase. Since the only known physiological function of catalase is to reduce $\mathrm{H}_{2} \mathrm{O}_{2}$ to water and oxygen (32), these results strongly support the conclusion that the generation of $\mathrm{H}_{2} \mathrm{O}_{2}$ is involved in the inhibitory effect of D-penicillamine and copper. Additional evidence for the role of $\mathrm{H}_{2} \mathrm{O}_{2}$ in this inhibitory effect includes the finding that both horseradish peroxidase and myeloperoxidase, two enzymes capable of degrading $\mathrm{H}_{2} \mathrm{O}_{2}$, were also protective of $\mathrm{T}$ lymphocyte responsiveness. Moreover, in preliminary observations it was found that all of the effects of the mixture of D-penicillamine and copper could be reproduced by $\mathrm{H}_{2} \mathrm{O}_{2}$ or other organic hydroperoxides such as tert-butyl hydroperoxide (unpublished observation). Finally, a number of other studies have demonstrated the inhibitory effect of $\mathrm{H}_{2} \mathrm{O}_{2}$ on T lymphocyte responsiveness (33).

The current studies, moreover, support the conclusion that $\mathrm{T}$ lymphocytes may be more sensitive to the inhibitory action of $\mathrm{H}_{2} \mathrm{O}_{2}$ than either $\mathrm{B}$ lymphocytes or monocytes, since these cells were far more sensitive to inhibition by the mixture of $D$ penicillamine and copper $(7,8)$. In preliminary experiments we have confirmed that $\mathrm{H}_{2} \mathrm{O}_{2}$ appears to be more toxic to $\mathrm{T}$ lymphocyte than to $\mathrm{B}$ cell or monocyte function, as would be anticipated from the results obtained with D-penicillamine and copper. The reason for this apparent selective toxicity is unclear, but may relate more to the capacity of the cells to degrade $\mathrm{H}_{2} \mathrm{O}_{2}$ than to inherent differences in their susceptibility to $\mathrm{H}_{2} \mathrm{O}_{2}$-mediated damage. Certainly, monocytes contain a number of enzymatic mechanisms to degrade $\mathrm{H}_{2} \mathrm{O}_{2}(20)$, which appear to be lacking in $\mathrm{T}$ cells (Table VIII).

A recent report has suggested that an additional cell population is also highly sensitive to the effects of $\mathrm{H}_{2} \mathrm{O}_{2}$. Thus, Seaman et al. (20) found that natural killer (NK) cell function was also inhibited by $\mathrm{H}_{2} \mathrm{O}_{2}$. In preliminary experiments we have confirmed these results and extended them to demonstrate that NK function is also very sensitive to inhibition by the mixture of D-penicillamine and copper (unpublished observations), again supporting the conclusion that the mixture of D-penicillamine and copper is capable of generating $\mathrm{H}_{2} \mathrm{O}_{2}$. The observation that NK function can be inhibited by the action of D-penicillamine and copper may have some importance in understanding the mechanism of action of this drug in rheumatoid arthritis. In this regard, Silver et al. (34) have recently demonstrated the presence of large numbers of activated NK cells in rheumatoid synovial fluid. In addition to its effect on $\mathrm{T}$ cell function, therefore, D-penicillamine may also be active in rheumatoid arthritis by virtue of its capacity to suppress the function of NK cells at the inflammatory site.

The mechanism by which the mixture of D-penicillamine and copper generates $\mathrm{H}_{2} \mathrm{O}_{2}$ has not been explored in detail. However, previous investigators have shown that cupric ions or $\mathrm{Cp}$ have the capacity to oxidize thiol compounds with the production of superoxide anions and $\mathrm{H}_{2} \mathrm{O}_{2}$. Some controversy exists concerning whether D-penicillamine is an appropriate substrate for this reaction (28-30). However, in the current studies it is clear that the mixture of D-penicillamine and Cp at the concentrations used and with the incubation medium used is capable of generating adequate $\mathrm{H}_{2} \mathrm{O}_{2}$ to cause $\mathrm{T}$ cell toxicity. In the current studies, $\mathrm{H}_{2} \mathrm{O}_{2}$ appears to be generated as the result of the direct chemical interaction between $\mathrm{CuSO}_{4}$ or $\mathrm{Cp}$ and D-penicillamine without the necessity for the presence of cells. Thus, in preliminary experiments carried out with Dr. $R$. Estabrook, in which $\mathrm{H}_{2} \mathrm{O}_{2}$ production was measured using a Clark type oxygen electrode, we were able to demonstrate the nearly instantaneous production of $\mathrm{H}_{2} \mathrm{O}_{2}$ as the result of mixing $\mathrm{CuSO}_{4}$ with D-penicillamine in a cell-free system (unpublished observation). When D-penicillamine $(100 \mu \mathrm{g} / \mathrm{ml})$ was mixed with $\mathrm{CuSO}_{4}, 32 \mu \mathrm{M}$ of $\mathrm{H}_{2} \mathrm{O}_{2}$ were generated within $30 \mathrm{~s}$. The amount of $\mathrm{H}_{2} \mathrm{O}_{2}$ produced was dependent on the concentration of both D-penicillamine and $\mathrm{CuSO}_{4}$.

It is likely that the initial product of the oxidation of Dpenicillamine by $\mathrm{CuSO}_{4}$ or $\mathrm{Cp}$ is the superoxide anion as has previously been reported for the $\mathrm{Cp}$ catalyzed oxidation of cysteine (30). Thus, for example, when superoxide was removed from the culture without the production of $\mathrm{H}_{2} \mathrm{O}_{2}$ by adding oxidized cytochrome $c$, which serves as a substrate for superoxide-mediated reduction (35), protection of the cells was observed. This finding supports the conclusion that the superoxide anion is initially generated by the interaction of D-penicillamine and $\mathrm{CuSO}_{4}$ or $\mathrm{Cp}$. However, the superoxide anion does not appear to mediate toxicity as evidenced by the finding that SOD does not protect the cells from the mixture of D-penicillamine and copper. It is unclear whether or not the production of $\mathrm{H}_{2} \mathrm{O}_{2}$ in this system is related to the spontaneous dismutation of the superoxide anion to $\mathrm{H}_{2} \mathrm{O}_{2}$ or whether this reaction is catalyzed by either $\mathrm{Cp}$ or penicillamine-copper complexes that may form in culture, each of which has been shown to have SOD activity $(14,36)$. In any event, the data support the conclusion that $\mathrm{H}_{2} \mathrm{O}_{2}$ is intimately involved in the inhibition of $\mathrm{T}$ cell function.

The mechanism whereby $\mathrm{H}_{2} \mathrm{O}_{2}$ inhibits $\mathrm{T}$ cell function remains to be elucidated. It appears that $\mathrm{H}_{2} \mathrm{O}_{2}$ itself is the toxic moiety and not additional oxygen radicals, such as hydroxyl radicals, which may be generated from chemical reactions involving $\mathrm{H}_{2} \mathrm{O}_{2}$ (37). Thus, for example, hydroxyl radical scavengers such as mannitol or dimethylsulfoxide had no protective effect on the inhibition of $T$ cell function caused by $D$-penicillamine and copper. Moreover, $\mathrm{Fe}^{2+}$ ions, which could catalyze the generation of hydroxyl radicals from $\mathrm{H}_{2} \mathrm{O}_{2}(38)$, had no effect on the degree of inhibition seen in these cultures $(7,17)$. Thus, it is likely that $\mathrm{H}_{2} \mathrm{O}_{2}$ itself is the toxic principle.

The effect of the mixture of D-penicillamine and copper on $T$ lymphocyte function was found to be mitigated by the presence of intact monocytes. This effect did not appear to relate to nonspecific uptake by monocytes of either D-penicillamine or $\mathrm{CuSO}_{4}$, since similar effects were seen when $\mathrm{H}_{2} \mathrm{O}_{2}$ itself was used as the inhibitory moiety. Rather it appeared that one or a number of heat-labile enzymes contained within the monocytes was responsible for this protective effect. Although myeloperoxidase could accomplish this, it was not required, as aged 
monocytes, which lacked myeloperoxidase, were able to protect $T$ lymphocytes from the effects of D-penicillamine and copper. Two candidate enzymes for this protective effect are catalase and glutathione peroxidase. Both of these enzymes are capable of degrading $\mathrm{H}_{2} \mathrm{O}_{2}$ and are heat labile $(20,22)$. The explanation for the finding that aged monocytes protected more effectively than fresh ones is not entirely clear, especially since the major candidate enzymes for conveying this protection, namely catalase and glutathione peroxidase, have not been shown to increase during 2-3 d of in vitro incubation (21). The observation that the protection of $\mathrm{T}$ cell function afforded by monocytes was sensitive to sodium azide indicates that the heme-containing enzyme, catalase, was the predominant enzymatic mechanism involved. Thus, the capacity of catalase to degrade $\mathrm{H}_{2} \mathrm{O}_{2}$ is completely inhibited by sodium azide (reference 21 , Table IX), whereas the concentration of sodium azide used $(1 \mathrm{mM})$ has no effect at all on the activity of glutathione peroxidase (Dr. R. F. Burk, personal communication). The conclusion that catalase and not glutathione peroxidase is the major enzyme involved in the protection of $\mathrm{T}$ cells from $\mathrm{H}_{2} \mathrm{O}_{2}$-mediated damage is supported by the results of a number of investigators who found that the glutathione redox system is predominantly involved in protecting phagocytes from internally generated oxidative stress occurring during phagocytosis (39-41), where catalase appears to be more important in the protection against external oxidative injury (41).

Other cell types likely to be found within rheumatoid synovium were much less able to protect $T$ cells from the effects of D-penicillamine and $\mathrm{CuSO}_{4}$ than monocytes. Thus, neither endothelial cells, nor fibroblasts, nor synovial cells prevented this inhibitory effect. Additional cells, however, may be able to protect $T$ cells from these inhibitors. Thus, for example, erythrocytes or polymorphonuclear leukocytes (41) with a rich content of both glutathione peroxidase and catalase (22) might be expected to convey such an effect. In preliminary experiments, we have found that human erythrocytes or erythrocyte lysates effectively protect $\mathrm{T}$ cells from the inhibitory effects of the mixture of $\mathrm{D}$ penicillamine and $\mathrm{CuSO}_{4}$ or $\mathrm{H}_{2} \mathrm{O}_{2}$. These results suggest that the interplay of cells present at the inflammatory site could well have an important role in determining the overall response to D-penicillamine therapy in patients with rheumatoid arthritis.

In summary, the in vitro experiments described here have suggested a mechanism by which D-penicillamine may be effective in rheumatoid arthritis. D-Penicillamine has the capacity to generate $\mathrm{H}_{2} \mathrm{O}_{2}$ in the presence of copper or $\mathrm{Cp}$, which in turn inhibits a number of $\mathrm{T}$ lymphocyte functions. Although the work presented here examined the effect of $\mathrm{D}$-penicillamine and $\mathrm{CuSO}_{4}$ on mitogen-induced $\mathrm{T}$ cell $\left[{ }^{3} \mathrm{H}\right]$ thymidine incorporation, previous studies have indicated that helper $\mathrm{T}$ cell function is also markedly depressed by these agents (8) and preliminary evidence has indicated that this inhibitory action is mediated by $\mathrm{H}_{2} \mathrm{O}_{2}$ production, since it is prevented by catalase (unpublished observation). A number of observations have indicated that $T$ cells play a central role in the perpetuation of rheumatoid inflammation. Thus, for example, the synovium is heavily infiltrated with $\mathrm{T}$ cells (42), many of which are activated as evidenced by their expression of HLA-DR antigens (43). Moreover, maneuvers designed to remove $\mathrm{T}$ lymphocytes such as thoracic duct drainage have been shown to be effective in the treatment of rheumatoid arthritis (44). Thus, suppression of $T$ cell function regionally by $D$-penicillamine in the presence of $\mathrm{Cp}$ provides a reasonable explanation for the capacity of this agent to suppress rheumatoid inflammation.

\section{Acknowledgments}

I would like to thank Ms. Patricia Thompson for her expertise in carrying out the experiments and Ms. Debbie McInnis for her skillful preparation of the manuscript.

This work was supported by U. S. Public Health Service program project grant AM-09989.

\section{References}

1. Multicentre Trial Group. 1973. Controlled trial of $D(-)$-penicillamine in severe rheumatoid arthritis. Lancet. I:275-280.

2. Dixon, A., St. J., J. Davies, T. L. Dormandy, E. B. D. Hamilton, P. J. L. Holt, R. M. Mason, M. Thompson, J. C. P. Weber, and D. W. Zutshi. 1975. Synthetic D-penicillamine in rheumatoid arthritis. Doubleblind controlled study of high and low dosage regimen. Ann. Rheum. Dis. 34:416-421.

3. Berry, H., S. P. Liyanage, R. A. Durance, C. G. Barnes, L. A. Berger, and S. Evans. 1976. Azathioprine and penicillamine in treatment of rheumatoid arthritis: a controlled trial. Br. Med. J. I:1052-1054.

4. Mery, C., F. Delrieu, R. Ghozlan, L. Saporta, F. Simon, B. Amor, C. J. Menkes, and F. Delbarre. 1976. Controlled trial of D-penicillamine in rheumatoid arthritis. Scand. J. Rheumatol. 5:241-247.

5. Shiokawa, Y., Y. Horiuchi, M. Honma, T. Kageyama, T. Okada, and T. Azuma. 1977. Clinical evaluation of D-penicillamine by multicentric double-blind comparative study in chronic rheumatoid arthritis. Arthritis Rheum. 20:1464-1472.

6. Zvaifler, N. J. 1973. The immunopathology of joint inflammation in rheumatoid arthritis. Adv. Immunol. 16:265-336.

7. Lipsky, P. E., and M. Ziff. 1978. The effect of D-penicillamine on mitogen-induced human lymphocyte proliferation: synergistic inhibition by D-penicillamine and copper salts. J. Immunol. 120:10061013.

8. Lipsky, P. E., and M. Ziff. 1980. Inhibition of human helper T cell function in vitro by D-penicillamine and $\mathrm{CuSO}_{4}$. J. Clin. Invest. 65:1069-1076.

9. Sorenson, J. R. J. 1976. Copper chelates as possible active forms of the antiarthritic agents. J. Med. Chem. 19:135-148.

10. Whitehouse, M. W., L. Field, C. W. Denko, and R. Ryall. 1975. Is penicillamine a precursor drug. Scand. J. Rheumatol. 4(Suppl. 8): 183.

11. Lipsky, P. E. 1981. Modulation of T lymphocyte function by copper and thiols. Agents Actions. 8(Suppl.):85-102.

12. Gubler, C. J., M. E. Lahey, G. E. Cartwright, and M. M. Wintrobe. 1953. Studies on copper metabolism. IX. The transportation of copper in blood. J. Clin. Invest. 32:405-414.

13. Rosenberg, S. A., and P. E. Lipsky. 1979. Monocyte dependence of pokeweed mitogen-induced differentiation of immunoglobulin-se- 
creting cells from human peripheral blood mononuclear cells. J. Immunol. 122:926-931.

14. Goldstein, I. M., H. B. Kaplan, H. S. Edelson, and G. Weissmann. 1979. Ceruloplasmin. A scavenger of superoxide anion radicals. J. Biol. Chem. 254:4040-4045.

15. Huber, C. T., and E. Frieden. 1970. Substrate activation and the kinetics of ferroxidase. J. Biol. Chem. 245:3973-3978.

16. Ashida, E. R., A. R. Johnson, and P. E. Lipsky. 1981. Human endothelial cell-lymphocyte interaction. Endothelial cells function as accessory cells necessary for mitogen-induced human $T$ lymphocyte activation in vitro. J. Clin. Invest. 67:1490-1499.

17. Rogoff, T. M., and P. E. Lipsky. 1979. Characterization of isolated guinea pig Kupffer cells: accessory cells function in mitogen-induced $\mathrm{T}$ lymphocyte activation. J. Immunol. 123:1920-1927.

18. Markowitz, H., C. J. Gubler, J. P. Mahoney, G. E. Cartwright, and M. M. Wintrobe. 1955. Studies on copper metabolism. XIV. Copper, ceruloplasmin, and oxidase activity in sera of normal human subjects, pregnant women, and patients with infection, hepatolenticular degeneration, and the nephrotic syndrome. J. Clin. Invest. 34:1498-1508.

19. Fridovich, I. 1975. Superoxide dismutases. Annu. Rev. Biochem. 44:147-159.

20. Seaman, W. E., T. D. Gindhart, M. A. Blackman, B. Dalal, N. Talal, and Z. Werb. 1982. Suppression of natural killing in vitro by monocytes and polymorphonuclear leukocytes. Requirement for reactive metabolites of oxygen. J. Clin. Invest. 69:876-888.

21. Nakagawara, A., C. F. Nathan, and Z. A. Cohn. 1981. Hydrogen peroxide metabolism in human monocytes during differentiation in vitro. J. Clin. Invest. 68:1243-1252.

22. Paglia, D. E., and W. N. Valentine. 1967. Studies on the quantitative and qualitative characterization of erythrocyte glutathione peroxidase. J. Lab. Clin. Med. 70:158-169.

23. Stadtman, T. C. 1980. Selenium-dependent enzymes. Annu. Rev. Biochem. 49:93-110.

24. Lipsky, P. E., and M. Ziff. 1977. Inhibition of antigen- and mitogen-induced human lymphocyte proliferation by gold compounds. J. Clin. Invest. 59:455-466.

25. Salmeron, G., and P. E. Lipsky. 1982. Immunosuppressive activity of chloroquine: inhibition of human monocyte function. Arthritis Rheum. 24:S132.

26. Frieden, E. 1980. Caeruloplasmin: a multifunctional metalloprotein of vertebrate plasma. Ciba Found. Symp. 79:93-124.

27. Al-Timimi, D. J., and T. L. Dormandy. 1977. The inhibition of lipid autooxidation by human ceruloplasmin. Biochem. J. 168:283288.

28. Albergoni, V., and A. Cassini. 1975. The oxidation of cysteine by ceruloplasmin. FEBS (Fed. Eur. Biochem. Soc.) Lett. 55:261-264.

29. Feldman, S. L., J. S. V. Hunter, A. Zgirski, V. M. Chidambaram, and E. Frieden. 1982. Comparison of the catalytic oxidation of cysteine and $o$-dianisidine by cupric ion and ceruloplasmin. J. Inorg. Biochem. 17:51-60.
30. Zgirski, A., M. V. Chirdambaram, and E. Frieden. 1982. Comparison of the catalytic activities of mammalian ceruloplasmin. In Inflammatory Diseases and Copper. J. R. J. Sorenson, editor. Humana Press, Clifton, NJ. 171-180.

31. Scudder, P. R., W. McMurray, A. G. White, and T. L. Dormandy. 1978. Synovial fluid copper and related variables in rheumatoid and degenerative arthritis. Ann. Rheum. Dis. 37:71-72.

32. Schonbaum, G. R., and B. Chance. 1976. Catalase. In The Enzymes. P. D. Boyer, editor. Academic Press, Inc., New York. Third ed. 13:363-379.

33. Fisher, R. I., and F. Bostick-Bruton. 1982. Depressed T cell proliferative responses in Hodgkin's disease: role of monocyte-mediated suppression via prostaglandins and hydrogen peroxide. J. Immunol. 129:1770-1774.

34. Silver, R. M., D. Redelman, N. J. Zvaifler, and S. Naides. 1982. Studies of rheumatoid fluid lymphocytes. I. Evidence for activated natural killer (NK)-like cells. J. Immunol. 128:1758-1763.

35. McCord, J. M., and I. Fridovich. 1969. Superoxide dismutase. An enzymatic function for erythrocuprein (hemocuprein). J. Biol. Chem. 244:6049-6055.

36. Younes, M., and U. Weser. 1977. Superoxide dismutase activity of copper-penicillamine: possible involvement of $\mathrm{Cu}(1)$ stabilized sulphur radical. Biochem. Biophys. Res. Commun. 78:1247-1253.

37. Novogrodsky, A., A. Ravid, A. L. Rubin, and K. H. Stenzel. 1982. Hydroxyl radical scavengers inhibit lymphocyte mitogenesis. Proc. Natl. Acad. Sci. USA. 79:1171-1174.

38. Klebanoff, S. J. 1982. The iron- $\mathrm{H}_{2} \mathrm{O}_{2}$-iodide cytotoxic system. J. Exp. Med. 156:1262-1267.

39. Oliver, J. M., D. F. Albertini, and R. D. Berlin. 1976. Effects of glutathione-oxidizing agents on microtubule assembly and microtubule-dependent surface properties of human neutrophils. J. Cell Biol. 71:921-932.

40. Burchill, B. R., J. M. Oliver, C. B. Pearson, E. D. Leinbach, and R. D. Berlin. 1978. Microtubule dynamics and glutathione metabolism in phagocytizing human polymorphonuclear leukocytes. J. Cell Biol. 76:439-447.

41. Roos, D., R. S. Weening, A. A. Voetman, M. L. J. van Schaik, A. A. M. Bot, L. J. Meerhof, and J. A. Loos. 1979. Protection of phagocytic leukocytes by exogenous glutathione: studies in a family with glutathione reductase deficiency. Blood. 53:851-866.

42. van Boxel, J. A., and S. A. Paget. 1975. Predominantly T-cell infiltrate in rheumatoid synovial membranes. N. Engl. J. Med. 293:517520.

43. Burmester, G. R., D. T. Y. Yu, A.-M. Irani, H. G. Kunkel, and R. J. Winchester. 1981. Ia+ cells in synovial fluid and tissues of patients with rheumatoid arthritis. Arthritis Rheum. 24:1370-1376.

44. Paulus, H. E., H. I. Machleder, S. Levine, D. T. Y. Yu, and N. S. MacDonald. 1977. Lymphocyte involvement in rheumatoid arthritis. Studies during thoracic duct drainage. Arthritis Rheum. 20:1249_ 1262. 